This Accepted Author Manuscript is copyrighted and published by Elsevier. It is posted here by agreement between Elsevier and University of Brasilia. Changes resulting from the publishing process - such as editing, corrections, structural formatting, and other quality control mechanisms - may not be reflected in this version of the text. The definitive version of the text was subsequently published in [Animal Reproduction Science, Volume 87, Issues 1-2, June 2005, Pages 45-57, doi:10.1016/j.anireprosci.2004.09.003].You may download, copy and otherwise use the AAM for non-commercial purposes provided that your license is limited by the following restrictions:

(1) You may use this AAM for non-commercial purposes only under the terms of the CC-BY-NCND license.

(2) The integrity of the work and identification of the author, copyright owner, and publisher must be preserved in any copy.

(3) You must attribute this AAM in the following format: [agreed attribution language, including link to CC BY-NC-ND license + Digital Object Identifier link to the published journal article on Elsevier's ScienceDirect ${ }^{\circledR}$ platform].

Este Manuscrito do Autor Aceito para Publicação (AAM) é protegido por direitos autorais e publicado pela Elsevier. Ele esta disponível neste Repositório, por acordo entre a Elsevier e a Universidade de Brasília. As alterações decorrentes do processo de publicação - como a edição, correção, formatação estrutural, e outros mecanismos de controle de qualidade - não estão refletidas nesta versão do texto. A versão definitiva do texto foi posteriormente publicado em [Animal Reproduction Science, Volume 87, Número 1-2, Junho de 2005, Páginas 45-57, doi:10.1016/j.anireprosci.2004.09.003]. Você pode baixar, copiar e utilizar de outra forma o AAM para fins não comerciais, desde que sua licença seja limitada pelas seguintes restrições:

(1) Você pode usar este AAM para fins não comerciais apenas sob os termos da licença CC- BYNC-ND.

(2) A integridade do trabalho e identificação do autor, detentor dos direitos autorais e editor deve ser preservado em qualquer cópia.

(3) Tem de atribuir este AAM no seguinte formato: [acordo na linguagem atribuída, incluindo o link para CC BY-NC-ND licença Digital + DOI do artigo publicado na revista Elsevier ScienceDirect ${ }^{\circledR}$ da plataforma]. 


\title{
Morphometric and ultrastructural characterization of Bos indicus preantral follicles
}

\author{
Mirella Ávila Kacinskis \\ Carolina Madeira Lucci \\ Maria Carolina Aquino Luque \\ Sônia Nair Báo
}

\begin{abstract}
The aim of the present study was to characterize the ultrastructure of zebu cow preantral follicles (PAFs). Ovarian cortex samples were processed for light and transmission electron microscopy. Primordial follicles consisted of an oocyte surrounded by one layer of flattened or flattened-cuboidal granulosa cells. The oocyte contained a large and usually eccentric nucleus. Most organelles were located at the perinuclear ooplasm. Round shaped mitochondria, which contained electron-dense granules, smooth and rough endoplasma reticulum and a Golgi apparatus were also observed. Vesicles and coated pits were often observed in the cortical ooplasm. In primary follicles, the oocyte was surrounded by one layer of cuboidal granulosa cells. Short microvilli were observed on the oolema. Secondary follicles consisted of an oocyte surrounded by a variable number of layers of cuboidal granulosa cells. Small secondary follicles had an ultrastructure very similar to that observed in primary follicles. At this follicular stage, the zona pellucida was beginning to form around the oocyte. In large secondary follicles, the zona pellucida was totally developed around the oocyte. Several granulosa cell projections could be detected that were encroaching into the zona pellucida and protruding towards the oocyte, where gap junctions were observed between oocyte and granulosa cell membranes. Organelles within the oocyte were located at the periphery of the ooplasm, and clusters of cortical granules were observed. Round mitochondria were abundant in all developmental stages. In conclusion, this study described the ultrastructure of zebu cow PAFs, and some unique characteristics could be observed as compared with what has been reported for follicles of Bos taurus cattle.
\end{abstract}

Keywords: Preantral follicles; Zebu cattle; Morphometry; Ultrastructure; Histology

\section{Introduction}

In the past decades, much attention has been given to the use of reproductive technologies in both endangered and economically important species. The first targets of these technologies were spermatozoa and embryos, but recently, studies involving the female gamete of various species are becoming more frequent. For this reason, the knowledge of the morphology and physiology of the oocyte is needed and this knowledge will probably be useful in the development of such techniques.

Many studies have been done in order to describe the oocyte and follicular structure of several domestic species, including sheep (Turnbull et al., 1977, Cran et al., 1980 and Cahill 
and Mauléon, 1981), goats (Lucci et al., 2001), cats (Jewgenow and Göritz, 1995), dogs (Durrant et al., 1998), pigs (Greenwald and Moor, 1989) and cattle (Hulshof et al., 1994, Beckers et al., 1996 and Van Wezel and Rodgers, 1996; Fair et al., 1997a and Fair et al., 1997b; Hyttel et al., 1997). These studies have shown that many characteristics are similar among species, but others may differ.

Although there are many studies about the ultrastructure and characterization of bovine follicles and oocytes, most of them were performed in European cattle. Other studies, however, have shown that European cattle (Bos taurus) differ from zebu cattle (Bos indicus) in various aspects of their reproductive biology (Chenoweth, 1994, Rocha et al., 1998 and Visintin et al., 2002). Many attempts have been made in developing the reproductive technologies for zebu cattle, especially because these animals are economically important to Brazil. However, very few studies have been developed to describe the morphology of ovarian follicles in B. indicus ( Assey et al., 1994a and Basso and Esper, 2002). The present work aimed, therefore, to morphologically characterize ovarian preantral follicles from zebu cattle (B. indicus) using light and transmission electron microscopy.

\section{Material and methods}

\subsection{Source and manipulation of ovaries}

Zebu cow ovaries were collected at a local abattoir and transported to the laboratory at $32-34{ }^{\circ} \mathrm{C}$ within $1-3 \mathrm{~h}$. In the laboratory, the ovaries were cleaned of adhering tissue and rinsed with $70 \%$ ethanol and sterile saline solution. Pieces of ovarian cortex were processed for classical histology and transmission electron microscopy.

\subsection{Classical histology procedures}

Ovarian pieces processed for classical histology were fixed in Carnoy fixative for 4-6 h, dehydrated in ethanol, clarified with xylene and embedded in paraplast (Histosec, Merck, Darmstadt, Germany). Sections ( $5 \mu \mathrm{m}$ thick) were cut and stained with periodic acid of Schiff and hematoxylin (PAS staining system, Sigma diagnostics, Inc., St. Louis, MO) and examined under a Zeiss Axiophot light microscope (Oberkochen, Germany). 


\subsection{Transmission electron microscopy procedures}

Small pieces of ovarian cortex were fixed in $2 \%$ paraformaldehyde, $2.5 \%$ glutaraldehyde in $0.1 \mathrm{M}$ sodium cacodylate buffer $(\mathrm{pH} 7.3)$ and post fixed in $1 \%$ osmium tetroxide, $0.8 \%$ potassium ferricyanide and $5 \mathrm{mM}$ calcium chloride in $0.1 \mathrm{M}$ sodium cacodylate buffer. The samples were then dehydrated in acetone and embedded in Spurr resin. Semi-thin sections $(3 \mu \mathrm{m})$ were stained with toluidine blue. Ultra-thin sections $(70 \mathrm{~nm})$ were stained with uranyl acetate and lead citrate and examined in a Jeol JEM 100C (Tokyo, Japan) transmission electron microscope.

\subsection{Follicle characterization}

For histological description, preantral follicles were classified as primordial, primary or secondary according to the shape and number of layers of granulosa cells. Follicular and oocyte diameters were measured using an ocular micrometer, and the granulosa cells were counted, both in the section where the nucleolus of the oocyte was observed (equatorial section). Follicles that presented pyknotic bodies in granulosa cells, condensed oocyte nucleus, shrunken oocyte or low cellular density were considered naturally degenerated (atretic follicles), and therefore were not used for the morphometric characterization.

For description by transmission electron microscopy, the characteristics of oocyte and granulosa cells, their organelles, basal membrane and zona pellucida were observed. Only follicles that were of normal morphology on semi-thin sections were ultrastructurally evaluated. In the present work, nine primordial follicles, five primary follicles and eight secondary follicles (five small and three large) were evaluated by transmission electron microscopy.

\subsection{Statistical analysis}

Follicle and oocyte diameters and number of granulosa cells at the equatorial section were compared among follicular classes. Data were analyzed by ANOVA and Scheffe's test (StatView for Windows, SAS Institute Inc., Cary, NC, USA). Values were considered statistically significant when $\mathrm{P}<0.05$. 


\section{Results}

\subsection{Histology}

Primordial follicles consisted of an oocyte surrounded by one layer of flattened or flattened-cuboidal granulosa cells. In these follicles, cuboidal granulosa cells, when present, were usually located on opposite poles of the follicles, giving them an elongated appearance. In primary follicles, the oocyte was surrounded by one layer of cuboidal granulosa cells. Secondary follicles consisted of an oocyte surrounded by two or more layers of cuboidal granulosa cells, but the number of layers greatly varied. Morphometric variable for primordial, primary and small secondary follicles are presented in Table 1. Secondary follicles that were larger than $120 \mu \mathrm{m}$ in diameter were not considered in the morphometric evaluation because there were too few of them with a nucleus and nucleolus in the evaluated sections.

Table 1

Follicle and oocyte diameter and number of granulosa cells of primordial, primary and secondary follicles from zebu cattle (mean \pm S.E.M.)

\begin{tabular}{lllll}
\hline Follicular classes & $N$ & $\begin{array}{l}\text { Follicle diameter } \\
(\mu \mathrm{m})(\mathrm{range})\end{array}$ & $\begin{array}{l}\text { Oocyte diameter }(\mu \mathrm{m}) \\
(\mathrm{range})\end{array}$ & $\begin{array}{l}\text { Number of granulosa } \\
\text { cells (range) }\end{array}$ \\
\hline Primordial & 80 & $36.0 \pm 0.9^{\mathrm{a}}(25-50)$ & $28.1 \pm 0.6^{\mathrm{a}}(20-35)$ & $7.3 \pm 0.4^{\mathrm{a}}(1-13)$ \\
Primary & 66 & $48.5 \pm 1.4^{\mathrm{b}}(35-70)$ & $31.7 \pm 0.7^{\mathrm{b}}(25-45)$ & $14.6 \pm 0.7^{\mathrm{b}}(10-29)$ \\
Small secondary & 33 & $88.4 \pm 2.9^{\mathrm{c}}(70-120)$ & $43.8 \pm 1.4^{\mathrm{c}}(35-56)$ & $62.0 \pm 4.6^{\mathrm{c}}(35-111)$ \\
\hline
\end{tabular}

Values with different superscripts $(\mathrm{a}-\mathrm{C})$ differ within column $(\mathrm{P}<0.05)$.

\subsection{Transmission electron microscopy}

\subsubsection{Primordial follicle oocyte}

The quiescent oocyte was ovoid or spherical, with a very homogeneous cytoplasm and a large, and usually eccentric nucleus (Fig. 1). The chromatin was uncondensed and one or two nucleolus could often be observed. The most abundant organelles were the round shaped mitochondria, which presented few peripheral cristae and electron-dense granules. Elongated mitochondria were rarely observed. In primordial follicle oocytes, some mitochondria presented a membrane dividing their matrix into two or more compartments (Fig. 2). Rough endoplasma reticulum cisternae were observed in most cases in association with mitochondria, but were also seen isolated within the cytoplasm (Fig. 3). Small cisternae of Golgi apparatus were sometimes observed. Vesicles were seen throughout the cytoplasm. The cellular membranes of oocyte and granulosa cells were in close connection, and coated pits were often observed in the cortical ooplasm (Fig. 4). 


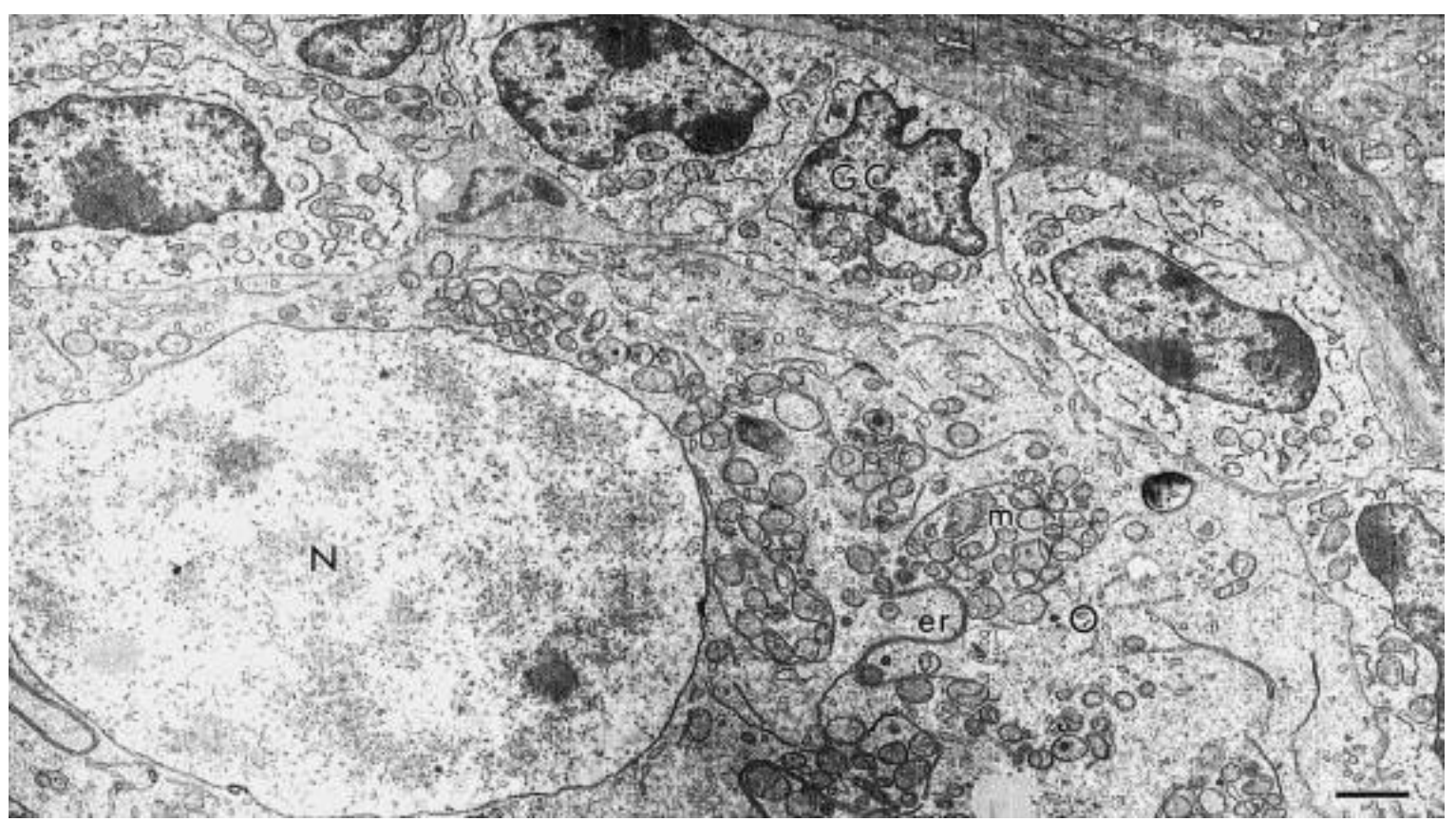

Fig. 1. Overview of a primordial follicle. Note the abundance of round shaped mitochondria in association with the endoplasma reticulum. O: oocyte; GC: granulosa cell; N: nucleus; m: mitochondria; er: endoplasma reticulum. Bar $=2 \mu \mathrm{m}$.

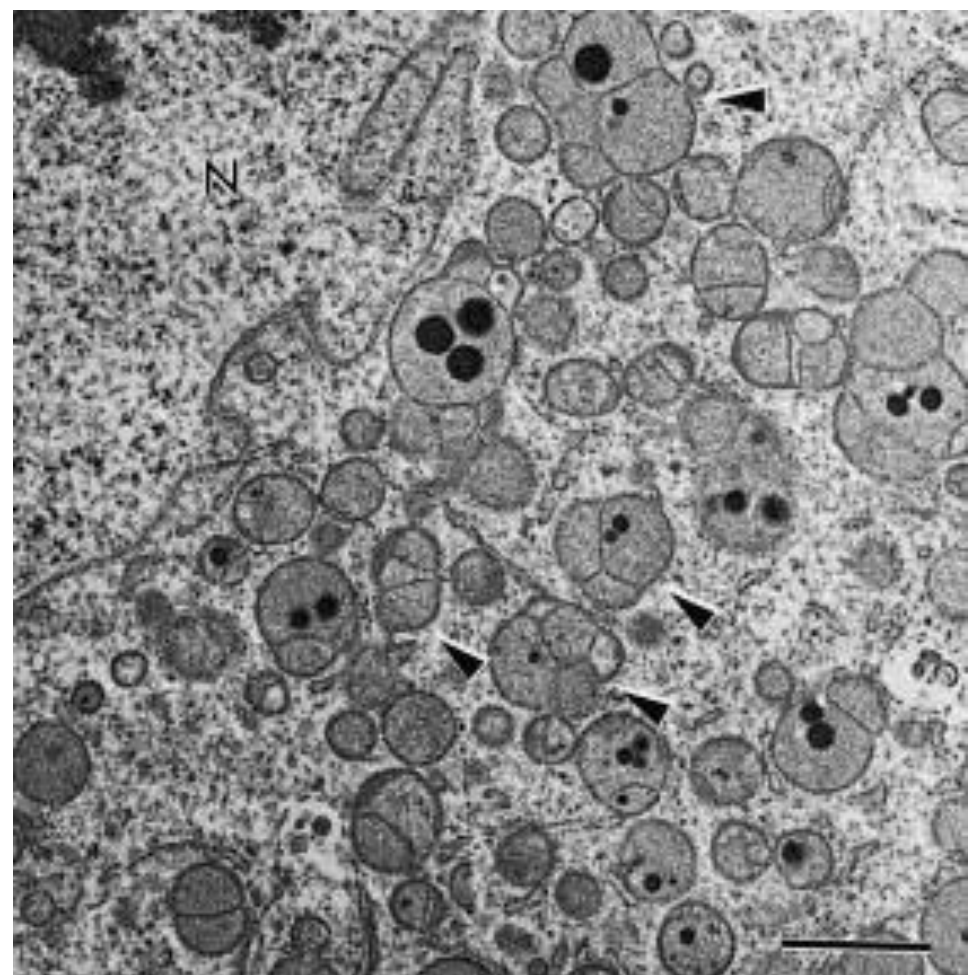

Fig. 2. Dividing mitochondria (arrowheads). Note the presence of electron-dense granules. N: nucleus of the oocyte. Bar $=2 \mu \mathrm{m}$. 


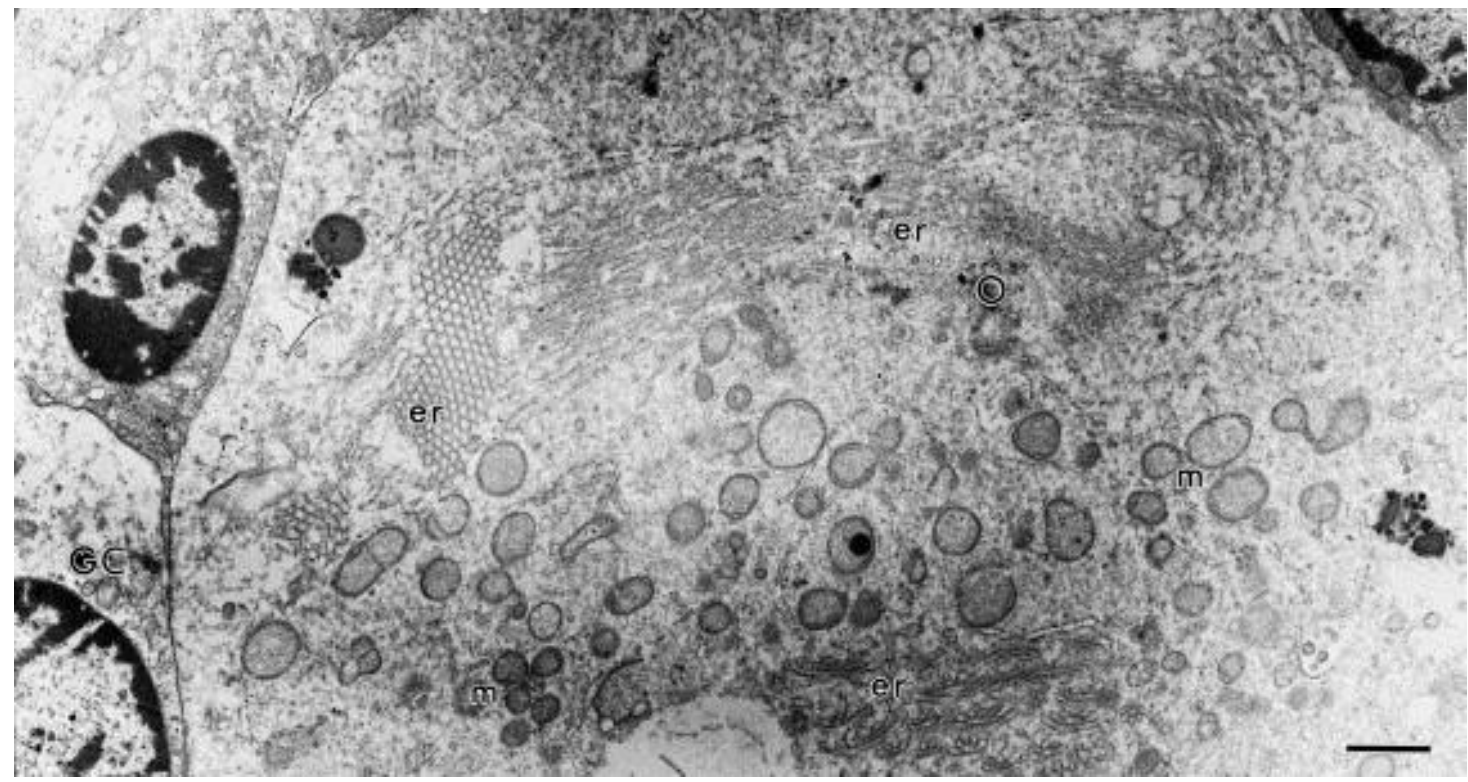

Fig. 3. Primordial follicle showing aggregates of the endoplasma reticulum in the ooplasm. O: oocyte; GC: granulosa cell; m: mitochondria; er: endoplasma reticulum. Bar $=2 \mu \mathrm{m}$.

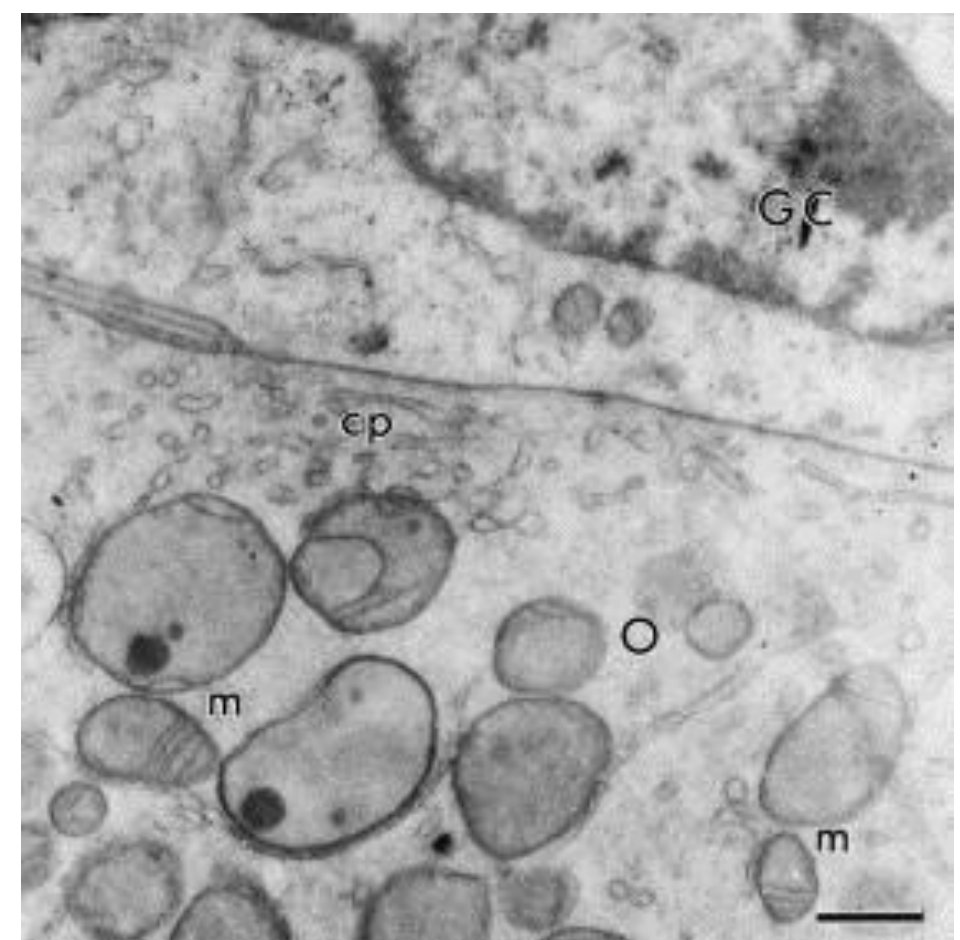

Fig. 4. Close connection between oocyte and granulosa cell membranes in a primordial follicle. O: oocyte; GC: granulosa cell; m: mitochondria; $c p$ : coated pits. Bar $=1 \mu \mathrm{m}$.

\subsubsection{Primary follicle oocyte}

Primary follicle oocytes were predominantly spherical, but elongated oocytes were observed in some cases. Oocyte cytoplasm occupied all spaces between the oocyte and granulosa cells, often invading spaces between two granulosa cells. Some short microvilli and numerous coated pits were observed (Fig. 5). Round mitochondria remained abundant and 
continued to have membranes dividing their matrix into compartments as was observed in primordial follicles. The endoplasma reticulum and Golgi apparatus cisternae were also present. The large eccentrical nucleus was very similar to that observed in the primordial stage.

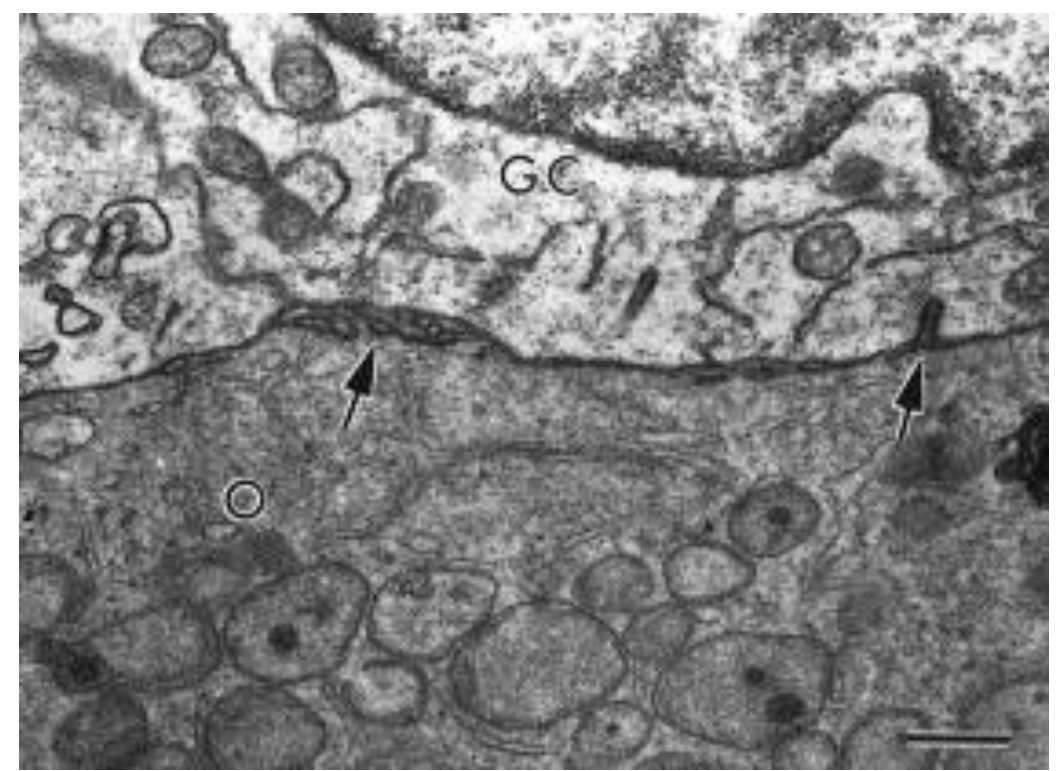

Fig. 5. Connection between oocyte and granulosa cells in a primary follicle. Arrows show short bent microvilli. O: oocyte; GC: granulosa cell. Bar $=1 \mu \mathrm{m}$.

\subsubsection{Secondary follicles}

Secondary follicles were divided into small and large follicles, and several differences were observed among these sizes concerning cell organization and structure. Small secondary follicles were less developed and had an ultrastructure very similar to that observed in primary follicles. At this follicular stage the zona pellucida was beginning to form around the oocyte.

Large secondary follicles were more developed. At this stage, the zona pellucida was fully developed, forming a thick layer around the oocyte, and short erect microvilli could be seen (Fig. 6). Several granulosa cell projections could be seen encroaching into the zona pellucida and protruding towards the oocyte, where gap junctions were observed between oocyte and granulosa cell membranes (Fig. 7). Organelles within the oocyte were located at the periphery of the ooplasm, leaving an organelle-free zone next to the nucleus (Fig. 8). Round mitochondria were still more abundant, but elongated mitochondria were also observed. The endoplasma reticulum cisternae were aggregated and abundant. Small clusters of cortical granules were initially observed in large secondary follicle oocytes. These were the innermost organelles, and were located at the edge of the perinuclear zone (Fig. 8 and Fig. 9). The large nucleus presented a fibrillo-granular nucleolus (Fig. 9). Vesicles were more common than in the earlier stages, but were not abundant, and myelin figures were common (Fig. 10). 


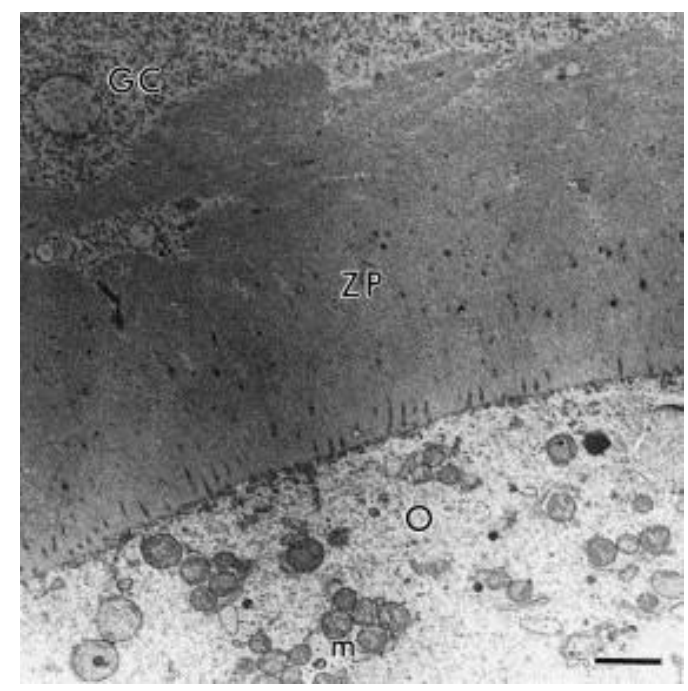

Fig. 6. A large secondary follicle with a totally developed zona pellucida where many erect microvilli can be seen. Note that round mitochondria are still present in the oocyte at this follicular developmental stage. O: oocyte; m: mitochondria; ZP: zona pellucida; GC: granulosa cell area. Bar $=2 \mu \mathrm{m}$.

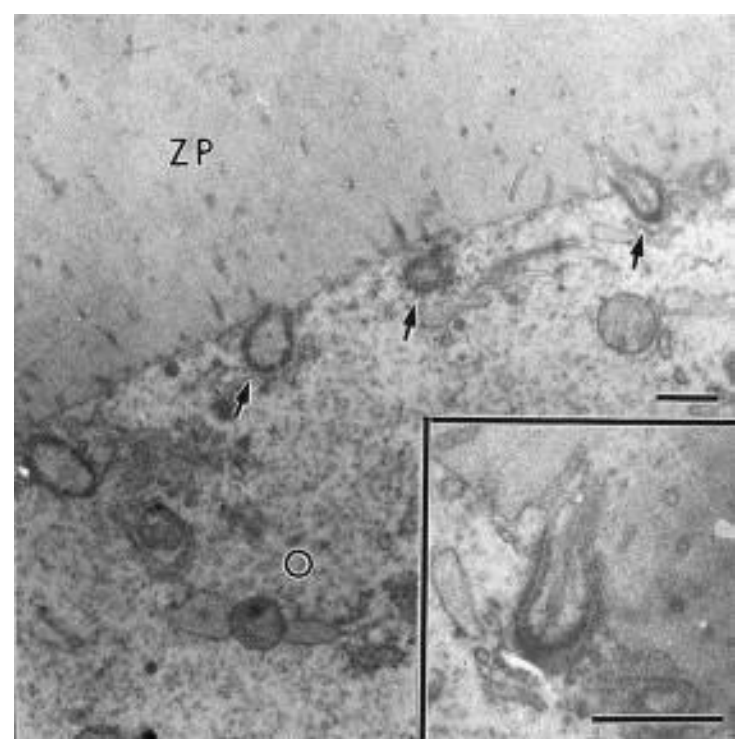

Fig. 7. Granulosa cell projections ending in gap junctions (arrows) with the oocyte in a large secondary follicle. A closer view of one of these projections can be seen in the insert. O: oocyte; ZP: zona pellucida. Bars $=1 \mu \mathrm{m}$.

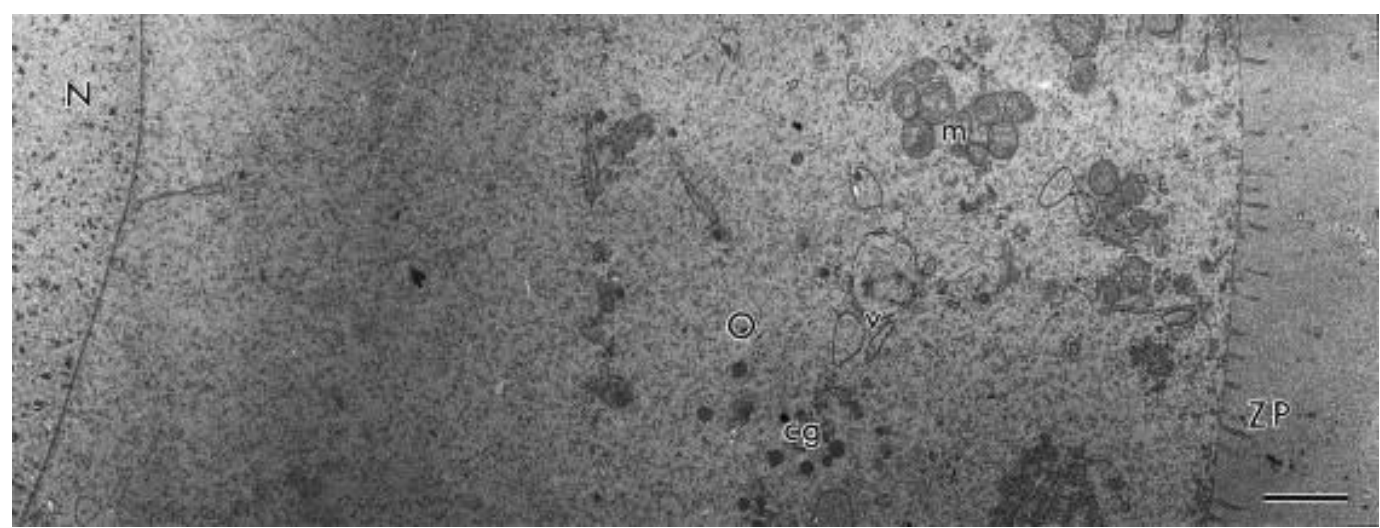

Fig. 8. Large secondary follicle oocyte showing an organelle-free zone close to the nucleus. Clusters of cortical granules can be seen as the innermost structure in the cortical ooplasm. O: oocyte; N: nucleus; m: mitochondria; v: vesicles; cg: cortical granules; ZP: zona pellucida. Bar $=2 \mu \mathrm{m}$. 


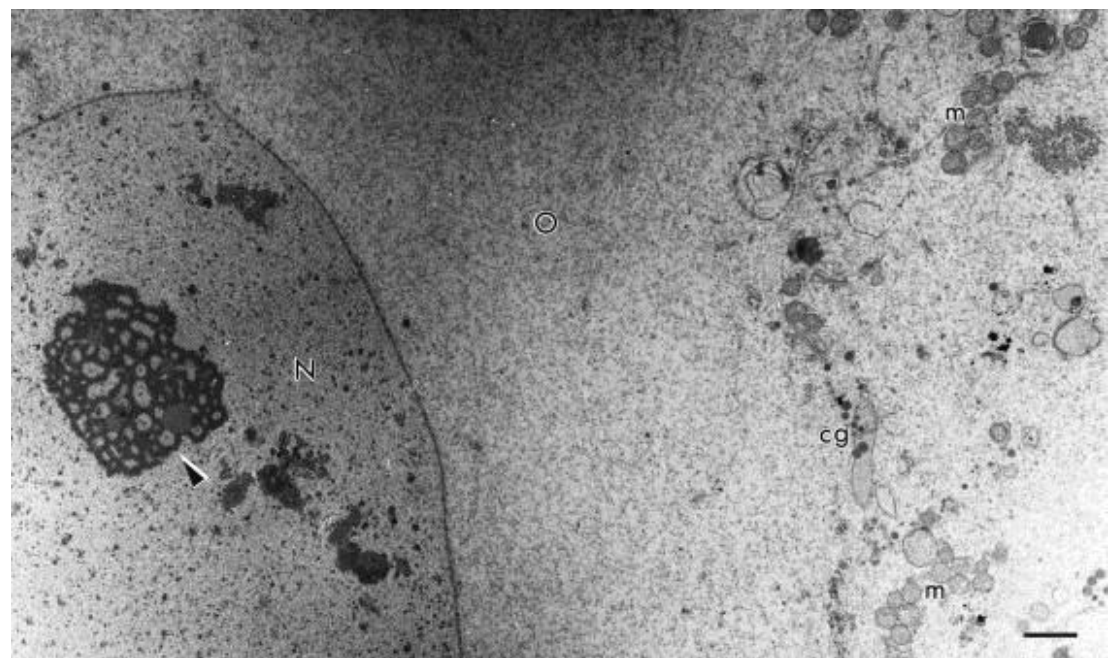

Fig. 9. Oocyte of a large secondary follicle. Observe the fibrillo-granular nucleolus (arrowhead). O: oocyte; N: nucleus; m: mitochondria; cg: cortical granules. Bar $=2 \mu \mathrm{m}$.

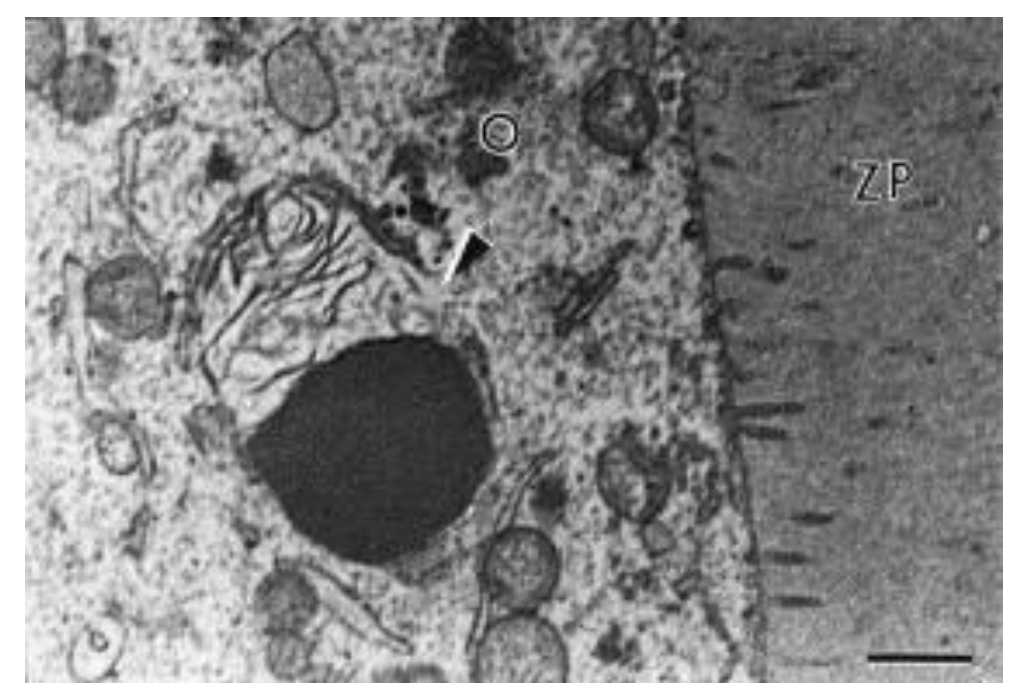

Fig. 10. Myelin figure (arrowhead) observed in large secondary follicles. O: oocyte; ZP: zona pellucida. Bar $=1 \mu \mathrm{m}$.

\subsubsection{Granulosa cells and basal membrane}

In all developmental stages, granulosa cells were small, with a greater nuclear:cytoplasmic ratio as compared with typical cell structures. The nuclei were irregularly shaped, with loose chromatin in the inner part, and small peripheral aggregates of condensed chromatin. Round and elongated mitochondria and smooth and rough endoplasma reticulum were the most evident organelles. Elongated granulosa cells had elongated nuclei (Fig. 11A), while cuboidal granulosa cells had very irregular shaped nuclei (Fig. 11B). In large secondary follicles, some granulosa cells had lost contact with each other, giving place to small antral fluid filled areas. Follicles were always surrounded by a basal membrane, which was tightly attached to the ovarian stroma. 

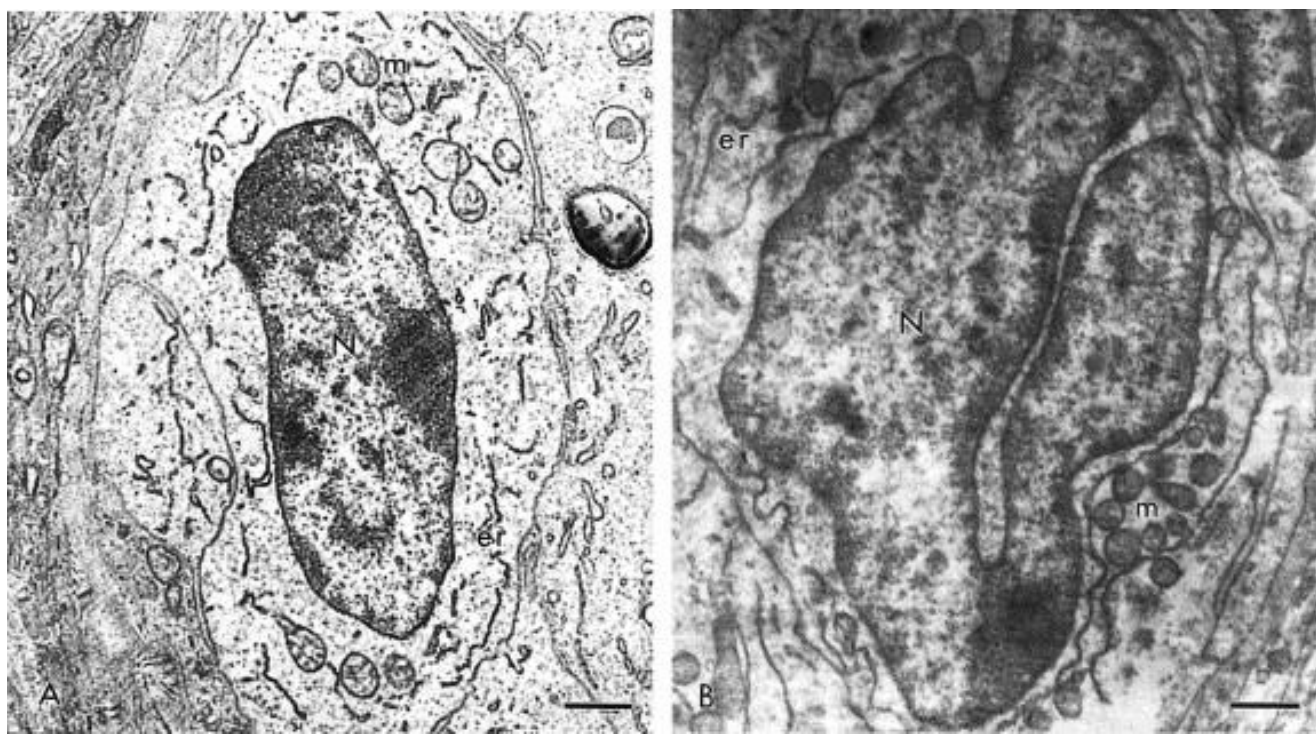

Fig. 11. Elongated (A) and cuboidal (B) granulosa cells. N: nucleus; $\mathrm{m}$ : mitochondria; er: endoplasma reticulum. Bars $=1 \mu \mathrm{m}$.

\section{Discussion}

The present study describes the changes in the morphology and ultrastructure of zebu preantral follicles during their development. The results showed that the mean diameter of zebu oocytes and follicles and the mean number of granulosa cells at the equatorial section were similar to those observed for European cattle (Van Wezel and Rodgers, 1996, Braw-Tal and Yossefi, 1997 and Hyttel et al., 1997) in all three developmental stages evaluated (i.e., primordial, primary and small secondary follicles). Also, our results were similar to those described for humans (Lintern-Moore et al., 1974), but different from those described for ewes (Lundy et al., 1999) and goats (Lucci et al., 2001).

In general, the ultrastructure observed in zebu (B. indicus) preantral follicles was similar to that described for European cattle (B. taurus) ( Van Wezel and Rodgers, 1996; Fair et al., 1997a and Fair et al., 1997b; Hyttel et al., 1997), but some differences were observed. The most important difference observed concerned the mitochondria. Round mitochondria are commonly found in oocytes, and were described in European cattle ( Fair et al., 1997a and Hyttel et al., 1997) and goats ( Lucci et al., 2001), especially in primordial and primary follicles. According to Fair et al. (1997a), round mitochondria are representative in immature forms of this organelle that develop to an elongated shape as they become mature. The presence of immature mitochondria in early developmental stages is consistent with primordial follicles containing a quiescent oocyte that does not require a large amount of energy to survive. The study of Fair et al. (1997a) provided evidence that secondary follicles contain a larger number of elongated mitochondria. In the present study, however, we observed that round 
mitochondria were consistently present, and were the most abundant type of mitochondria in all the follicular developmental stages studied. In one antral follicle evaluated under the transmission electron microscope, elongated mitochondria were abundant, however, round mitochondria were still observed (data not shown). Also, in some oocytes of early stages (primordial and primary) a membrane could be seen dividing the mitochondrial matrix into two or three compartments, suggesting that the mitochondria were going through a dividing process. The proliferation of mitochondria is very important to increase the energy producing capacity of growing cells. The metabolic activation of primordial follicle oocytes and the subsequent growth of primary follicle oocytes demand greater than typical amounts of energy to allow the cell to go through the necessary modifications and eventually achieve meiotic competence.

Moreover, both round and elongated mitochondria contained one to three round, large electron-dense granules inside their matrix. The presence of mitochondrial granules has not been reported before in European cattle oocytes, but Assey et al. (1994b) observed electron-dense granules in some mitochondria of zebu cattle oocytes. Small dense granules in the mitochondrial matrix are very common in some cell types, such as liver, nephron and pancreatic acinar cells. These have been reported to be especially prominent in tissues transporting large amounts of ions or water, and it is suggested that these granules are concerned with the regulation of the internal ionic environment of the mitochondrion (Fawcett, 1966).

Concerning communications between oocyte and granulosa cells, it was observed in the present study that numerous coated pits were present at all developmental stages studied, indicating a communication mediated through endocytotic ways. This type of communication requires a very close contact between cells that may explain the proximal distribution of the oocyte. Oocytes were located very close to granulosa cells, often invading spaces between two granulosa cells. In secondary follicles, a decreased number of coated pits was observed while numerous gap junctions were seen, with granulosa cell projections being visible through all the oolema. This can be explained by the formation of the zona pellucida that blocks the close contact between oocyte and granulosa cells. Coated pits are commonly observed in early preantral follicles of cattle (Fair et al., 1997a and Hyttel et al., 1997) and other species (Lucci et al., 2001), while gap junctions are more commonly observed in more developed follicles, especially after the development of the zona pellucida (Assey et al., 1994a, Fair et al., 1997a and Hyttel et al., 1997). 
In the present study, the nucleolar dynamics of the oocytes followed the same pattern described by Fair et al. (1997b) in a specific study concerning oocyte nuclear activity. In general, the nucleolus of resting primordial oocytes consists of a granular reticulum of homogeneous electron density that can be permeated by small vesicles. After follicle activation, fibrillar centers were observed within the granular reticulum. According to Fair et al. (1997b), these changes prepare the nucleolus for the transcriptional activity that will take place in late secondary follicles.

Myelin figures observed in large secondary follicles are thought to represent digestive vesicles responsible for degradation of old and non-functional cellular structures (Fawcett, 1966). Oocytes are cells with a very long developmental stage, taking years to leave the quiescent stage and then months to get fully developed. This way, the renewal of organelles may be necessary, and the myelin figures observed may represent digestive vesicles of aged oocyte organelles.

In conclusion, the present work represents a detailed description of the morphometry and ultrastructure of zebu cattle preantral follicles. In general, zebu preantral follicles are morphologically similar TO that described in European cattle, but some unique characteristics were observed. In the future, basic knowledge on the ultrastructure of preantral follicles of zebu cattle may facilitate the understanding of their in vitro development.

\section{Acknowledgements}

This research was supported by Conselho Nacional de Desenvolvimento Científico e Tecnológico (CNPq).

\section{References}

Assey, R.J., Hyttel, P., Kanuya, N., 1994a. Oocyte structure in dominant and subordinate follicles in zebu cattle (Bos indicus). Anat. Embryol. 190, 461-468.

Assey, R.J., Hyttel, P., Roche, J.F., Boland, M.P., 1994b. Infrequent structures in cattle oocytes. Anat. Embryol. 190, 263-271.

Basso, C.A., Esper, C.R., 2002. Isolamento e caracterizac, ao ultraestrutural de fol 'ıculos preantrais de vacas da raça Nelore (Bos taurus indicus). Braz. J. Vet. Res. Anim. Sci. 39, 311-319.

Beckers, J.F., Drion, P.V., Figueiredo, J.R., Goffin, L., Pirottin, D., Ectors, F.J., 1996. The ovarian follicle in cow: in vivo growth and in vitro culture. Reprod. Dom. Anim. 31, 543-548.

Braw-Tal, R., Yossefi, S., 1997. Studies in vivo and in vitro on the initiation of follicle growth in the bovine ovary. J. Reprod. Fert. 109, 165-171. 
Cahill, L.P., Mauleon, P., 1981. A study of the populations of primordial and small follicles in the sheep. J. Reprod. Fert. 61, 201-206.

Chenoweth, P.J., 1994. Aspects of reproduction in female Bos indicus cattle: a review. Aust. Vet. J. 71, 422-426.

Cran, D.G., Moor, R.M., Hay, M.F., 1980. Fine structure of the sheep oocyte during antral follicle development. J. Reprod. Fert. 59, 125-132.

Durrant, B.S., Pratt, N.C., Russ, K.D., Bolamba, D., 1998. Isolation and characterization of canine advanced preantral and early antral follicles. Theriogenology 49, 917-932.

Fair, T., Hulshof, S.C.J., Hyttel, P., Greve, T., Boland, M., 1997a. Oocyte ultrastructure in bovine primordial to early tertiary follicles. Anat. Embryol. 195, 327-336.

Fair, T., Hulshof, S.C.J., Hyttel, P., Greve, T., Boland, M., 1997b. Nucleus ultrastructure and transcriptional activity of bovine oocytes in preantral and early antral follicles. Mol. Reprod. Dev. 46, 208-215.

Fawcett, D.W., 1966. An Atlas of Fine Structure - The Cell: Its Organelles and Inclusions, first ed. W.B. Saunders Company, Philadelphia and London.

Greenwald, G.S., Moor, R.M., 1989. Isolation and preliminary characterization of pig primordial follicles. J. Reprod. Fert. 87, 561-571.

Hulshof, S.C.J., Figueiredo, J.R., Beckers, J.F., Bevers, M.M., Van den Hurk, R., 1994. Isolation and characterization of preantral follicles from foetal bovine ovaries. Vet. Quart. 16, 78-80.

Hyttel, P., Fair, T., Callesen, H., Greve, T., 1997. Oocyte growth, capacitation and final maturation in cattle. Theriogenology 47, 23-32.

Jewgenow, K., Goritz, F., 1995. The recovery of preantral follicles from ovaries of domestic cats and their characterization before and after culture. Anim. Rep. Sci. 39, 285-297.

Lintern-Moore, S., Peters, H., Moore, G.P.M., Faber, M., 1974. Follicular development in the infant human ovary. J. Reprod. Fert. 39, 53-64.

Lundy, T., Smith, P., O'connell, A., Hudson, N.L., Mcnatty, K.P., 1999. Population of granulosa cells in small follicles of the sheep ovary. J. Reprod. Fert. 115, 251-262.

Lucci, C.M., Silva, R.V., Carvalho, C.A., Figueiredo, J.R., Bao, S.N., 2001. Light microscopical and ultrastructural characterization of goat preantral follicles. Small Rumin. Res. 41, 61-69.

Rocha, A., Randel, R.D., Broussard, J.R., Lim, J.M., Blair, R.M., Roussel, J.D., Godke, R.A., Hansel, W., 1998. High environmental temperature and humidity decrease oocyte quality in Bos taurus but not in Bos indicus cows. Theriogenology 49, 657-665

Turnbull, K.E., Braden, A.W.H., Mattner, P.E., 1977. The pattern of follicular growth and atresia in the ovine ovary. Aust. J. Biol. Sci. 30, 229-241.

Van Wezel, I., Rodgers, R.J., 1996. Morphological characterization of bovine primordial follicles and their environment in vivo. Biol. Reprod. 55, 1003-1011. 
Visintin, J.A., Martins, J.F.P., Bevilacqua, E.M., Mello, M.R.B., Nicacio, A.C., Assumpção M.E.O.A., 2002. Cryopreservation ofBos taurus vs.Bos indicus embryos: are they really different? Theriogenology 57, 345-359. 